\title{
Institutions Matter, But Which Ones?
}

Pranab Bardhan

University of California at Berkeley

\section{I}

In the last two decades institutional economics of development has been enriched by historical and, more recently, quantitative analysis of the effects of the quality of institutions on the pace and pattern of economic development. Following the leadership of Douglass North, this literature has shown how important secure property rights are in encouraging investment and innovations, allowing for the investor and the innovator to reap the harvest of their efforts. There is, however, a general impression in the literature as it has developed since then that if one can get the rule of law that protects property rights (and preferably, the laws themselves are of the Anglo-Saxon type which are supposed to protect minority shareholders against insider abuse in the corporate sector), the market will take care of much of the rest. This preoccupation of the literature with the institution of security of property rights, often to the exclusion of other important institutions, severely limits our understanding of the development process. For example, historically the way the various coordinating institutions in a society function has made a big difference in development. In general, economies at early stages of development are beset with coordination failures of various kinds and alternative coordination mechanisms -- the state, the market, the community organizations -- all can play different roles, sometimes conflicting and sometimes complementary, in overcoming these coordination failures, and these remain important even if private property rights were to be made fully secure. Also, these roles change in various stages of development in highly context-specific and path-dependent ways. To proclaim the universal superiority of one coordination mechanism over another is naive, futile and a-historical.

In dealing with coordination failures, and particularly in orchestrating institutional change from a low-level equilibrium to a better one, there are all kinds of collective action problems. In economics or political science we do not have yet good theories of collective action. But one 
strand of the literature on collective action has emphasized how distributive conflicts (with respect to both political and economic power) may make collective action difficult ${ }^{1}$, particularly at the level of provision of public goods and social infrastructure that are so crucial for development. In general distributive conflicts may be at the root of a great deal of institutional failures that are so common in poor countries. The purpose of this paper is thus to go beyond the narrow focus of the current institutional economics literature on the institutions protecting individual property rights, and to look at the economic effects of some other aspects of institutional quality; and to speculate why and how institutions that have an adverse effect on economic performance often tend to persist for long periods of time in many of these countries.

One reason some economists are hesitant to enter such murky territory is that it is difficult to quantify the effects of these other institutions, and so, according to the standard cliché about economists, we keep our search for the 'lost keys' confined to the more lighted area. But, for that matter, property rights institutions were not quantified, however inadequately, until very recently. In the next section we extend the existing literature on quantifying the effect of property rights institutions on income in two ways: (a) to introduce an alternative instrumental variable from history (state antiquity) to the one widely used in the recent literature (colonial settler mortality) and (b) to use an institutional variable like democratic participation rights in addition to the usual property rights variable. We find that both of these new variables can be statistically significant in cross-country regressions, and the latter particularly when the dependent variable is not income but instead some of the human development indicators (like literacy). But much of this paper is not quantitative. The emphasis here is more on providing an integrative and a somewhat reflective account of the main analytical issues. In section III we focus on the importance of social and political institutions that may have the potential of mitigating some of the pervasive coordination failures we have referred to, but their effects are hard to quantify and there is not much alternative to a comparative-historical analysis. In section IV we analyze the

1 For some preliminary attempt to study the theoretical effect of economic inequality on collective action in terms of a repeated-game model and to crudely measure the empirical effect in terms of the provision of a local public good, see chapters 10 and 11 in Bardhan (2005). For a brief survey of the literature on inequality and management of local commons, see Baland and Platteau (forthcoming). 
role of unequal property regimes and the resultant distributive conflicts in explaining why dysfunctional institutions often persist. Section V concludes.

\section{II}

As in much of institutional economics we are going to interpret institutions in the very general sense of rules of structured social interaction. In any society there is, of course, a plethora of such rules. In the literature on rural development at the micro-level there have been many attempts to quantify the impact of institutions like land tenure on productivity or of credit and risk-sharing institutions on consumption and production efficiency. For an overview of some of the major theoretical issues in that literature and empirical references, see Bardhan and Udry (1999). This overview, however, did not consider the macro-level, where there has been a flurry of empirical activity in the recent literature, largely on the basis of cross-country regressions, to determine the relative importance of geographical as opposed to institutional factors in explaining differential economic performance in different parts of the world. In this section I shall first follow the lead of two widely-cited references in this literature, Acemoglu, Johnson, and Robinson -- AJR (2001), and Rodrik, Subramanian and Trebbi -- RST (2004), carry out some extensions of their work, and then point to some of my reservations about this literature, before moving on to more general, possibly less quantifiable, issues.

AJR (2001) suggest that the mortality rates among early European settlers in a colony (obviously related to its geography and disease patterns) determined if the Europeans mainly concentrated on installing resource extractive or plundering institutions there or decided to settle and build European institutions like those protecting property rights. AJR (2001) use mortality rates of colonial settlers as an instrument for institutional quality, thus trying to avoid the problem of endogeneity of institutions vis-a-vis income. In our own exercise in this paper in explaining inter-country variations in per capita income we use the colonial settler mortality 
variable as one of the alternative instrumental variables. But we also use other or alternative instruments, other aspects of institutional quality, and other dependent variables.

I look for alternative instruments because I doubt if in many cases the colonial settler variable captures the major historical forces that have an impact on the social and economic institutional structure of an ex-colony. Just consider the markedly different historical forces shaping the institutions in ex-colonies (with quite bad disease environments) like Brazil, India or the Congo. Then there are those countries that mostly escaped colonization, ${ }^{2}$ like China or Thailand, or Ethiopia for most of history, and in such cases it will be improper (and much too Euro-centric an approach) to attribute underdevelopment largely to 'bad' colonial institutions imposed by Europeans.

In particular, countries with a long history of state structure and bureaucratic culture may have substantial institutional residues, even after the colonial interregnum, that may be quite different from countries which did not have that history. Bockstette, Chanda, and Putterman (2002) have computed an index of state antiquity for a large number of countries; it shows that among developing countries this index is much lower for sub-Saharan Africa and Latin America than for Asia, and even in Asia the index for Korea is several times that for the Philippines (a country that lacked an encompassing state before the 16th-century colonization by Spain). We quantify below some of the cross-country effects of this state antiquity index. In the case of many African countries not merely there is a relative lack of state antiquity (in the sense of a continuous territory-wide state structure above the tribal domains) in pre- colonial times, 3 they were artificially regrouped (and cartographically carved out in the state rooms of Europe) by the colonial rulers, so that the post-colonial state was often incongruent with pre-colonial political

2 As RST (2004) point out, the non-colonized group of countries includes some very high-income countries such as Finland and Luxembourg as well as very poor countries like Ethiopia, Yemen, and Mongolia, and these income differences cannot obviously be related to any colonial experience.

3 Herbst (2000) argues that in land-abundant Africa in the pre-colonial period, land rights were not well-defined, and political entities with vague borders and no well-defined territory to defend, did not invest in bureaucracies or fiscal and military institutions. 
structures and boundaries. This had a serious adverse effect on the legitimacy of the state ${ }^{4}$ and the efficacy of state institutions. ${ }^{5}$ One statistical advantage of using the state antiquity index instead of the settler mortality variable is that the sample size can be much larger, as information on the former is available for more countries than for the latter.

We also use two types of institutional variables, one relates to the rule of law in the sense of protection of property rights as in AJR (2001) and RST (2004), but the other relates to democratic political rights, more relating to 'voice' and participation. This is an aspect of institutional quality largely ignored in the relevant empirical literature in institutional economics. We find this to be particularly important when we consider as our dependent variable, apart from per capita income of countries, other indices of 'human development', like literacy and longevity and also the composite human development index of the UNDP.

While our two-stage regressions reconfirm the results of AJR (2001) in terms of the effectiveness of the colonial settler mortality variable as an instrument and the significance of the rule of law variable in influencing per capita income across countries (and also longevity and the human development index in our case), we add the results that the state antiquity measure (indicating a continuous history of state structure) can also sometimes act as an alternative reasonable instrument, and that the proxy for democratic political rights is a more significant determinant when literacy is the dependent variable, and is significant along with the rule of law variable in influencing other elements of the composite human development index. This may suggest that some aspects of human development may be advanced by the progress of democratic institutions, as by the establishment of property rights protection. 6

4 Most African states are low in the legitimacy scores given by Englebert (2000).

5 In some situations the different ethnic groups were never reconciled to unification under one state even at the beginning of its formation, as in the case of the Southerners in Sudan.

6 Some people associate democracy with security of private property rights. But I agree with Przeworski and Limongi (1993) when they say that "the idea that democracy protects property rights is a recent invention, and we think a far-fetched one". If the majority are poor, and the democratic processes work, the property rights of the rich minority may not always be secure. On the other hand, democracy is not necessary for security of property rights: durable authoritarian regimes have sometimes acquired reputation of providing a secure and predictable contractual environment for private business to thrive (examples from recent history in East and South-east Asia easily come to mind). 
In Table I we have the descriptive statistics for different variables, for three alternative sample size of countries (since data on some variables are not available for some countries). In Tables II and III we have the corresponding pair-wise correlation matrix ${ }^{7}$. Table IV provides the results of an ordinary least-squares (OLS) regression, suggesting that both the institutional variables considered, rule of law (RULE) and weak political rights (WPR) are highly significant in explaining variations in per capita income across countries. But, of course, as is easy to see, both of these institutional variables are endogenous and may be simultaneously affected by forces that govern per capita income. So we have recourse to the standard technique of instrumental variables (I.V.) regression.

In Table $\mathrm{V},{ }^{8}$ for a sample of 98 countries, Panel B shows the first-stage regression results where the measure of state antiquity (STATHIST) has a highly significant positive association with the rule-of-law variable (RULE), and ethno-linguistic fragmentation (ELF) has a highly significant negative association with it. This may suggest that continuity over a long period of some kind of supra-local bureaucratic structure over a particular territory may help the preservation of rule of law, whereas the collective action problems arising from social fragmentation may undermine it. For the corresponding second-stage equation for explaining both per capita GDP in 1995 and the life expectation at birth in 2000 and the composite human development index, the I.V. estimate of the coefficient on the institutional variable RULE is positive and significant. But when the literacy level in 2000 is the dependent variable, the I.V. estimate of the coefficient on RULE is not significant. Instead a different institutional variable, an index of weakness of political rights (WPR) is significant: the weaker are the political rights, the lower the literacy. This may suggest democratic voice and participation are conducive to mass literacy campaigns. In the first-stage regression WPR is significantly related to ELF, but not STATEHIST.

7 The number of observations is different from the other tables, because when the historical variables are not included we have data for a larger number of countries for the other variables.

8 All the equations in Table V pass the OID test (from regressing second-stage residual on the instrument set) at $5 \%$ level. 
In Table $\mathrm{V}$, we also have a smaller sample of 69 countries which allows us to utilize a historical (relating to the year 1500) population density variable (DENS). The results are similar to those described in the preceding paragraph, with the difference that at the first stage the significance of STATEHIST diminishes somewhat in influencing RULE, and DENS has a positive and significant association with weak political rights. At the second stage Literacy is again significantly and negatively associated with weakness of political rights. Our speculation about why in countries with historically high population density political rights are weaker in general is that in these countries with labor abundance and low market power of workers, equality of political power may have been more difficult to establish. This is consistent with a claim by Engerman and Sokoloff (2002) that areas of labor scarcity in the New World in the early colonial period saw more political equality (particularly in terms of voting rights and independence from large landlords).

In Table $\mathrm{V}$, for the smallest sample of 57 countries, we can introduce the European settler mortality variable of AJR in addition to the other variables. As before, in the second stage the I.V. estimate of the coefficient on RULE is significant all through except when the dependent variable is Literacy. For the latter WPR is significant as before. For the composite human development index in 2000 the I.V. estimates of the coefficient on RULE as well as on WPR are significant.

In the first-stage regression, as before, ethno-linguistic fragmentation and population density in 1500 are associated with weak political rights. The European settler mortality variable is significantly related to both of our institutional variables. The state antiquity variable is now (weakly) associated with weak political rights; this may suggest that countries with a long history of an entrenched bureaucratic-military set-up need not be hospitable to democratic rights, even when it maintains some rule of law regarding property rights.

Before we end this section let us comment on some of the general problems that afflict such cross-country regression exercises. Apart from the obvious qualms about the dubious 
quality and comparability of data for a large set of poor countries, the usual econometric problems loom large; even when the endogeneity problem is addressed, a serious omitted variable bias, particularly where there is no alternative to taking the lowest common denominator in terms of available country variables (the weakest chain in the country dataset determines what is doable), is largely unavoidable. In any case cross-national studies do not usually give us good insights into the mechanisms though which institutions affect development. There is also a tendency to read too much into the results based on the United Nations principle of 'one country, one vote' (which is anomalous in a situation where the large majority of countries are tiny and the substantial numbers of the poor in the world live in a handful of large countries), and institutions and the policies as actually implemented at the local level within a country are often quite diverse and heterogeneous, except for a few country-wide macroeconomic institutions like those governing monetary or exchange rate policy.

As for specific variables the now widely used colonial settler mortality variable, first introduced by AJR (2001), is actually quite problematic (hence the importance of the two regressions in our Table $\mathrm{V}$ which do not use this instrumental variable). It is not clear if the settler mortality variable excludes the effect of some other deeper factors. For example, density of population may be one such deeper factor; it has the direct effect that it is easier to settle in more sparsely populated areas, and the indirect effect that density is conducive to spread of some diseases. It has been suggested that the disease environment in the $18^{\text {th }}$ or $19^{\text {th }}$ century may be correlated with that in 2000, and the latter affects current incomes directly as well as through its effect on institutions. Then as Przeworski (2004) points out, the procedure of instrumenting recent institutions by referring to some old historical fact is flawed because institutions change over time. An instrument for the initial institutions need not be a valid instrument for the current ones. If good institutions are more likely to survive in more affluent countries, then institutional quality today is still endogenous with respect to income. Olsson (2005) has pointed out that some of the early colonies (say in Latin America) were run by Europeans (from Spain and 
Portugal) at a time when they did not have those property rights institutions quite in place even at home. ${ }^{9}$

Even ignoring these doubts, if we consider this variable as an acceptable instrument for the immediate statistical purpose of avoiding the problem of endogeneity of institutions vis-a-vis income by accounting for a part (though usually a rather small part) of the exogenous (i.e. not income-dependent) variations in institutional quality, we have earlier expressed our doubt if in many cases this captures the major historical forces that have an impact on the social and economic institutional structure of an ex-colony or gives us much of a clue about the underlying mechanisms involved. In general, much of the recent cross-country regressions literature seems more preoccupied with finding clever instruments, less in making sure that they really unearth an adequate and satisfactory causal explanation. In the inevitable absence of detailed and relevant data across a number of countries, we may have to often resort to general qualitative comparative-historical analysis of the development process in order to understand the impact of different kinds of institutional arrangements, and much of the rest of this paper is in that oldfashioned mode.

\section{III}

For Western Europe and North America such a comparative historical analysis of institutions in the development process has been successfully tried by North (1981), (1990) and Greif (1992), (1997). North has pointed to the inevitable tradeoff in the historical growth process between economies of scale and specialization on the one hand, and transaction costs on the other. In a small, closed, face-to-face peasant community, for example, transaction costs are low, but the production costs are high, because specialization and division of labor are severely limited by the extent of market defined by the personalized exchange process of the small

\footnotetext{
${ }^{9}$ Albouy (2004) corrects what he regards as some flaws in the AJR settler mortality measure and shows that when the revised data are used, the AJR analysis suffers from a 'weak
} 
community. In a large-scale complex economy, as the network of interdependence widens the impersonal exchange process gives considerable scope for all kinds of opportunistic behavior and the costs of transacting can be high. Greif examined the self-enforcing institutions of collective punishment for malfeasance in long-distance trade in the late medieval period and in a comparative study of the Maghribi and the Genoese traders explored the institutional foundations of commercial development.

In Western societies over time complex institutional (legal and corporate) structures have been devised to constrain the participants, to reduce the uncertainty of social interaction, in general to prevent the transactions from being too costly and thus to allow the productivity gains of larger scale and improved technology to be realized. These institutions include elaborately defined and effectively enforced property rights, formal contracts and guarantees, trademarks, limited liability, bankruptcy laws, large corporate organizations with governance structures to limit problems of agency, and, what Williamson (1985) has called ex post opportunism. Some of these institutional structures are non-existent or weak or poorly devised and implemented in less developed countries. The state in these countries is either too weak to act as a guarantor of these rights and institutions and/or much too predatory in its own demands, posing a threat to them.

Beyond the face-to-face village community, the institutions a society develops (or fails to develop) for long-distance trade, credit and other intertemporal and interspatial markets, where the transactions are not self-enforcing, provide an important indicator of that society's capacity for development. In this context the analysis of North (1990), Milgrom, North, and Weingast (1990), Greif (1992), and Greif, Milgrom, and Weingast (1994) have brought to our attention the importance of several institutions like the Merchant Guild (for example, those in Italian citystates or inter-city guilds like the German Hansa), the Law Merchant system (like private judges recording institutionalized public memory at the Champagne fairs which provided an important nexus of trade between northern and southern Europe), and the Community Responsibility System in the Mediterranean and European trade during the late medieval commercial revolution

instrument' problem. Acemoglu, Johnson, and Robinson (2005) vigorously challenge this and reaffirm their earlier results. 
in the period between the eleventh and the fourteenth century. These institutions facilitated economic growth by reducing opportunism in transactions among people largely unknown to one another and providing a multilateral reputation mechanism supported by frameworks of credible commitment, enforcement and coordination.

Many developing countries in the world have a long history of indigenous mercantile institutions of trust and commitment (based on multilateral reputation mechanisms and informal codes of conduct and enforcement) -- examples of such institutions of long-distance trade and credit abound among mercantile families and groups in pre-colonial and colonial India, Chinese traders in Southeast Asia, Arab 'trading diasporas' in West Africa, and so on. For pre-colonial India, for example, Bayly (1983) cites many cases of caste-based (and sometimes even multicaste) mercantile associations and panchayats (or local tribunals or arbitration panels), which acted much like the merchant guilds and the law merchant system respectively of medieval Europe, over a vigorous and far-flung mercantile economy. Credit instruments like the hundi (or bills of exchange), even though their negotiability was not always recognized in formal courts of law (in British India), governed trade across thousands of miles. Firms kept lists of creditable merchants whose credit notes -- sahajog hundis -- could expect a rapid discount in the bazaar. While Bayly writes about these community institutions primarily around the so-called burgher cities of Allahabad and Benares in pre-colonial north India, Rudner (1994) studies the south Indian caste-based mercantile organization of the Nattukottai Chettiars in the colonial period whose elaborate system of hundis over long distances (with the caste elite firms or adathis acting as the clearinghouses), collective decisions on standardization of interest rates, and caste panchayats with customary sanctions provided the basis of indigenous banking networks spread out in large parts of south India and British south-east Asia. For China, we can cite from $\mathrm{Ma}$ (2004) the cases of two of the historically largest merchant groups originating in Huizhou and Shanxi. The Huizhou merchants for many centuries organized networks of credit, capital and business partnership across distant trading towns, governed by elaborate rules, through lineage unions (lianzhong) - different lineages combining their genealogies (tongpu) and amalgamating under a common ancestor (often fictitious). The careful compilation and constant update of lineage genealogies served the function of information gathering and commercial networking. The 
Shanxi bankers who dominated the nationwide money transfer business for the whole of the $19^{\text {th }}$ century, however, made little use of lineage ties. Their recruitments of staff were restricted to Shanxi natives only, and through elaborate background checks, collective punishments for fraudulent behavior and profit-sharing incentives for employees built their formidable reputation in the banking business.

The institutional economics literature, however, suggests that the traditional institutions of exchange in developing countries often did not evolve into more complex (impersonal, open, legal-rational) rules or institutions of enforcement as in early modern Europe and emphasizes the need for such an evolution. But the dramatic success story of rapid industrial progress in Southeast Asia in recent decades often under the leadership of Chinese business families suggests that more 'collectivist' organizations can be reshaped in particular social-historical contexts to facilitate industrial progress, and clan-based or other particularistic networks can sometimes provide a viable alternative to contract law and impersonal ownership. In a study of 72 Chinese entrepreneurs in Hong Kong, Taiwan, Singapore, and Indonesia, Redding (1990) shows how through specific social networks of direct relationship or clan or regional connection they build a system dependent on patrimonial control by key individuals, personal obligation bonds, relational contracting, and interlocking directorships. ${ }^{10}$ As Ouchi (1980) had noted some years back, when ambiguity of performance evaluation is high and goal incongruence is low, the clanbased organization may have advantages over market relations or bureaucratic organizations. In clan-based organizations goal congruence (and thus low opportunism) is achieved through various processes of socialization; performance evaluation takes place through the kind of subtle reading of signals, observable by other clan members but not verifiable by a third-party authority. Punishment for breach of implicit contracts is usually through social sanctions and reputation

10 As Redding (1990) points out: "Many transactions which in other countries would require contracts, lawyers, guarantees, investigators, wide opinion-seeking, and delays are among the overseas Chinese dealt with reliably and quickly by telephone, by a handshake, over a cup of tea. Some of the most massive property deals in Hong Kong are concluded with a small note locked in the top drawer of a chief executive's desk, after a two-man meeting."

(One hears similar stories about the Hasidic diamond traders of New York and about firms in industrial districts in Northern Italy). 
mechanisms. Another advantage of such clan-based relations is flexibility and ease of renegotiation. 11

Of course, as may be expected, the arrangements in these business families and groups are somewhat constrained by too much reliance on centralized decision-taking and control, internal finance, small pool of managerial talent to draw upon, relatively small scale of operations, and in case of large organizations a tendency to subdivide into more or less separate units, each with its own products and markets. A major problem of such 'collectivist' systems of enforcement is that the boundaries of the collectivity within which rewards and punishment are practiced may not be the most efficient ones and they may inhibit potentially profitable transactions with people outside the collectivity. So as the scale of economic activity expands, as the need for external finance and managerial talent becomes imperative, and as large sunk investments increase the temptation of one party to renege, relational implicit contracts and reputational incentives become weaker. ${ }^{12}$ As Li (2003) has pointed out, relation-based systems of governance may have low fixed costs (given the pre-existing social relationships among the parties and the avoidance of the elaborate legal-juridical and public information and verification costs of more rule-based systems), but high and rising marginal costs (particularly of private monitoring) as business expansion involves successively weaker relational links.

In general, in the history of most developing countries, even when the indigenous institutions of a mercantile economy thrived, the process of development of sequentially more complex organizations suited for industrial investment and innovations as is familiar from the history of the West did not take place or was slow to come. Nationalist historiography in these countries has, of course, blamed this on colonial or neo-colonial policies. While not denying the

11 What Holmstrom and Roberts (1998) note for Japanese contracts between automakers and their suppliers is far more generally true in family- and clan based implicit contracts: “...the contracts between the Japanese automakers and their suppliers are short and remarkably imprecise, essentially committing the parties only to work together to resolve difficulties as they emerge. Indeed, they do not even specify prices, which instead are renegotiated on a regular basis....The key to making this system work is obviously the long-term repeated nature of the interactions." (p.81).

12 Some of the pros and cons of relational contracting are empirically studied in the case of Vietnam's emerging private sector by McMillan and Woodruff (1999). 
importance of the effects of these policies and the lasting wounds of colonialism, I shall largely confine myself in this paper to a discussion of indigenous institutional impediments to development, which may have been just as valid and significant for those poor countries which do not share a colonial history.

A major institutional deficiency that blocked the progress of the mercantile into the industrial economy in many poor countries relates to the financial markets. Even when castebased or clan-based mercantile firms thrived in their network of multilateral reputation and enforcement mechanisms, the latter were often not adequate for supporting the much larger risks of longer-gestation large sunk-cost industrial investment. These firms, by and large, had limited capacity (either in terms of finance or specialized skills) to pool risks and mobilize the capital of the society at large in high-risk high-return industrial ventures (their own reinvested profits and trade credit from suppliers were not enough). Diversified business groups, that are ubiquitous in developing countries, are sometimes regarded as active players in risk-sharing. With a new data set on business groups in 15 emerging markets, Khanna and Yafeh (2000) examine this, and find that while there is some corroborative evidence for this in Brazil, Korea, Taiwan and Thailand, this kind of co-insurance is not generally significant or adequate in the larger set of countries. 13

The usual imperfections of the credit and equity markets emphasized in the literature on imperfect information are severe in the early stages of industrial development. First of all, the investment in learning by doing is not easily collateralizable and is therefore particularly subject to the high costs of information imperfections. Aoki (2001) points to the importance of close relations between banks and firms, ${ }^{14}$ based on tacit, uncodified knowledge, at a stage when firms

13 With the existing data it is also difficult to distinguish empirically between risk-sharing and minority shareholder expropriation or 'tunneling'.

14 A study in Mexico-- see La Porta et al 2003)- associates such related lending with 'looting' of banks by related companies. Maurer and Haber (2004) have pointed out that the negative effects of related lending stem not from the practice itself but from the institutional context in which related lending takes place. Related lending in Mexico in 1995-98 took place in the context of an ongoing government bailout of depositors, bank debtors, and stockholders. They study the history of related lending in Mexico in the period from 1888 to 1913 (when there were high capital requirements and no deposit insurance) and find little evidence of tunneling or credit misallocation. These results are consistent with the findings of Lamoreaux (1994) about insider lending in New England 
are not yet ready for the securities market with its demands for codifiable and court-verifiable information. ${ }^{15}$ Very often such close relations between banks and firms require some support and underwriting of risks by a more centralized authority in situations of undeveloped capital markets, as well as tight centralized monitoring to prevent collusion and malfeasance.

Secondly, the technological and pecuniary externalities in investment between firms (and industries)--emphasized analytically (though difficult to pin down empirically) in early as well as more recent development literature-- give rise to 'strategic complementarities' and positive feedback effects resulting in multiple equilibria. ${ }^{16}$ This is particularly important, when externalities of information and the need for a network of proximate suppliers of components, services and infrastructural facilities with economies of scale make investment decisions highly interdependent, and private financiers willing and able to internalize the externalities of complementary projects and raise capital from the market for the whole complex of activities are often absent in the early stage of industrialization. Motivated by some historical examples from 19th century continental Europe, Da Rin and Hellmann (1996) show in a model with complementarities of investments of different firms that private banks can act as catalysts for industrialization provided that they are sufficiently large to mobilize a critical mass of firms, and that they possess sufficient market power to make profits from costly coordination. These necessary conditions were not met, for example, in the case of unsuccessful industrial banks in Spain and Russia in the 19th century. This is where government-mediated coordination may be potentially useful (though at the possible cost of dampening private incentives to discover or experiment with superior coordination tactics).

before the Civil War. For Thailand Menkhoff and Suwanaporn (2003) in an in-depth study of the lending decision of banks in 1992-96 (the pre-financial crisis period) from 560 credit files from the majority of Thai commercial banks comes to a conclusion about related lending quite different from that in La Porta et al (2003).

15 Aoki(2000) points out that even in the US venture capital financing of start-up firms has similar characteristics as in relational finance (as opposed to arm's length finance).

16 This has a long history in the postwar development literature from Rosenstein-Rodan (1943) to Murphy, Shleifer and Vishny (1989). The recent economic geography literature has emphasized similar kinds of strategic complementarities and agglomeration economies. 
Whereas Da Rin and Hellmann suggest that centralized financing may assist in resolving coordination problems rooted in the borrower's side of the market, Dewatripont and Maskin (1995) focus on the manner in which centralized financing may help to resolve coordination problems rooted in the lender's side of the market. In a model of decentralized banking system where capital ownership is diffuse, they show that banks tend to underinvest in long-term projects which involve large sunk costs requiring co-financing by several banks. This is because such co-financing leads to a free rider problem in monitoring by each bank. ${ }^{17}$

Historically, in some countries (for example, in postwar East Asia) the state has played an important role in resolving this kind of 'coordination failure' by facilitating and complementing private sector coordination. In this context one may note that Gerschenkron (1962) had emphasized the role of state-supported development banks for the late industrializers of Europe in the 19th century. Government-supported development banks (like the Crédit Mobilier in the 19th century France, or after the first World War, Crédit National in France and Societé National de Crédit á l'Industrie in Belgium, or after the second World War, Kredintaltanlt für Weidarufban in Germany, Japan Development Bank, the Korea Development Bank, and very recently, the China Development Bank) have played a crucial role in long-term industrial finance and acquisition and dissemination of financial expertise in new industrial sectors in periods of largescale reconstruction and acute scarcity of capital and skills in both past and recent history.

But their experience in other developing countries (say, in India or Mexico in recent decades) has been mixed at best. Armendáriz de Aghion (1999) points out that unlike in the former cases (particularly in France, Germany, and Japan), in the latter cases the development banks have often been controlled by the government in an exclusive and heavy-handed way, without scope for co-financing (or co-ownership) arrangements with private financial intermediaries (which help risk diversification and dissemination of expertise), and without the opportunity to specialize in a small number of sectors (that helps acquisition of specialized

17 There is actually a trade-off here. Decentralized financing may lead to not funding some socially worthwhile projects (Type 1 error), centralized financing, on the other hand, may lead to failure to terminate socially inefficient projects (Type 2 error). 
expertise in financing projects in targeted sectors). This is even apart from the usual moral hazard problem in subsidizing the sometimes necessary losses the pioneering development banks will make, and the ever-present dangers of loan operations getting involved in the political patronage distribution process.

Thus in the crucial leap between the mercantile economy and the industrial economy the ability of the state to act as a catalyst and a coordinator in the financial market can occasionally be important. In much of the literature on the new institutional economics the importance of the state is recognized but in the narrow context of how to use its power in the enforcement of contracts and property rights one the one hand and at the same time how to establish its credibility in not making confiscatory demands on the private owners of those rights on the other. This dilemma is implicit in the standard recommendation in this literature for a 'strong but limited' government.

It is, however, possible to argue that in the successful cases of East Asian development (including that of Japan) the state has played a much more active role, intervening in the capital market sometimes in subtle but decisive ways, using regulated entry of firms and credit allocation (sometimes threatening withdrawal of credit in not so subtle ways) in promoting and channeling industrial investment, underwriting risks and guaranteeing loans, establishing public development banks and other financial institutions, encouraging the development of the nascent parts of financial markets, and nudging existing firms to upgrade their technology and to move into sectors that fall in line with an overall vision of strategic developmental goals 18 . In this process, as Aoki, Murdock, and Okuno-Fujiwara (1997) have emphasized, the state has enhanced the market instead of supplanting it; it has induced private coordination by providing various kinds of cooperation-contingent rents. In early stages of industrialization when private financial and other related institutions were underdeveloped and coordination was not selfenforcing, the East Asian state created opportunities for rents conditional on performance or

18 For a recent account of the role of the state in facilitating and engendering coordination, networking, and technology upgrading in the electronics and information technology industry in Taiwan, see Lin (2003). 
outcome (in mobilization of savings, commercialization of inventions, export 'contests', and so on) and facilitated institutional development by influencing the strategic incentives facing private agents through an alteration of the relative returns to cooperation in comparison with the adversarial equilibrium. (Such contingent transfers are akin to the patent system, where the monopoly rent is contingent on successful innovation). The performance criteria in East Asia often included export success, which in a world of international competition kept the subsidized firms on their toes and encouraged cost and quality consciousness. The government commitment to maintain rents for banks, contingent on performance, also gives banks more of a stake in long run relations with firms and a stronger incentive to rescue investment projects that are suffering from temporary financial distress-- this is particularly important when in the absence of a vigorous and reliable stock market the risk-averse savers put much of their money in banks who lend it out to firms, who thereby acquire a high debt-equity ratio, making them particularly vulnerable to temporary shocks.

One should not, of course, underestimate the administrative difficulties of such aggregate coordination and the issues of micro-management of capital may be much too intricate for the institutional capacity and information processing abilities of many a state in Africa, Latin America, or South Asia. There is also the problem of how credible the commitment of the state is in implementing the contingent transfer and actually carrying out the threat of withdrawing the transfer when performance does not measure up. In this the states in Africa, Latin America, or South Asia have often been rather lax, compared to East Asia, and the contingent transfers have soon degenerated into unconditional subsidies or entitlements for favorite interest groups. One should also be wary, as the more recent East Asian experience of financial crisis warns us, about the moral hazard problems of too cozy a relationship between public banks and private business and the political pressures for bail-out that a state-supported financial system inevitably faces.

As economic stagnation has been prolonged in Japan in the last decade or so, the East Asian model has faded from public approbation. As pointed out by Aoki, Murdock, and OkunoFujiwara (1997), when technologies become more complex and the exploration of new technological opportunities becomes highly uncertain in a world of intense global competition and 
demands more flexibility in decision-making in the face of rapid changes, the state loses some of its efficacy in guiding private sector coordination and relation-based systems may delay active restructuring. ${ }^{19}$ It should be stressed, however, that this is not the major problem facing poor countries at their early stages of industrial transformation, when they are still struggling to reach the largely known production possibility frontier (though subject to problems of technology adaptation $^{20}$ ). I think in general the lessons of the East Asian model for early stages of industrial transformation in poor countries are being dismissed much too easily, pointing to the recent problems of Japan or South Korea, but given the choice many poor countries would rather be in their shoes now. In fact one arguable position is that the East Asian financial crisis has been less due to the failure of the developmental state, more a result of its partial and haphazard dismantling (giving up some of its traditional functions of coordinating investments--creating large-scale excess capacity in industries, and the financial regulations-- allowing lax monitoring particularly of the growth of short-term debt denominated in foreign currency). This dismantling preceded (for example, in the case of South Korea in the mid-90's, in a hurry to be accepted into the OECD fold) the onset of the financial crisis. And even through the years of crisis in neighboring countries the state-owned China Development Bank has been playing a dynamic role in lending to infrastructure projects and basic industries and catalyzing growth. The standard complaint that East Asian growth has been more in capital accumulation and less in total factor productivity is also of limited relevance for poor countries; almost all countries, including the

19 It may also be the case that the entry barriers that gave rise to the cooperation-contingent rent for the initial producers made it more difficult over time for new entrepreneurs to challenge incumbents, and this has slowed adoption of new technology. For a theoretical model of this, see Acemoglu (2003).

20 In a widely noted book Parente and Prescott (2000) have identified the main reason for low total factor productivity in developing countries as the barriers imposed by their governments to adopting internationally available technology and the opposition from influential special-interest groups like labor unions. These are, of course, important obstacles. But, as Pack (2003) points out in a review of this book, much of the effective use of technology is not codified, but implicit or tacit, and cannot be purchased from abroad. Domestic efforts to adapt and assimilate are critical, and in this government investment in market-supporting infrastructure and in research and training and extension are quite important. He compares the total factor productivity (TFP) in Chile after economic liberalization that was much more thorough than in Korea and Taiwan (the latter in the initial decades of industrial growth had a much more protective regime and gave more monopoly rights to domestic firms), and yet the productivity performance in the latter was better than in Chile. 
United States in large parts of the 19 th century, ${ }^{21}$ show a similar pattern in the early stages of industrialization.

In this section we have emphasized the role of community and state institutions in the necessary coordination functions in long-term finance in the early stages of industrial development. The recent literature on development finance puts much more stress on minority shareholder rights and protection against insider abuse. Just as the recent literature on institutional economics emphasized (and in some cases over-emphasized, as we discuss in section II) the impact of colonial legacy on post-colonial institutional performance over the last four to five decades, the empirical finance literature has sometimes made a distinction between the particular European sources of that legacy in terms of legal systems. For example, La Porta et al $(1997,1999)$ have called attention to the superior effects, across countries, of the Anglo-Saxon common-law system based on judicial precedents over the civil-law system based on formal codes, on corporate business environment both in terms of more flexibility with changing needs of business and in terms of better protection for external suppliers of finance to a company (whether shareholders or creditors). Apart from some doubts about the establishment of causality in these cross-national studies, one can also question the historical evidence in the rich countries themselves. Lamoreaux and Rosenthal (forthcoming) have done a comparative study of the constraints imposed by their respective legal system on organizational choices of business in the US (with its common law system) and France (with its civil-law codes) during the middle of the 19th century around the time when both countries were beginning to industrialize. They conclude that there was nothing inherent in the French legal regime that created either a lack of flexibility or a lack of attention to the rights of creditors or small stakeholders. Many of the rules in the US for minority shareholder rights actually came after the insider scandals of the Great Depression period. Rosenthal and Berglof (2003) also question the primacy of legal origin in explaining institutions of investor protection; drawing upon the legislative history of US bankruptcy law they show how the US, with an English common-law legal origin, ended up with a

21 See Eichengreen (2002). 
bankruptcy regime quite different from that in the UK, and how political and ideological forces shaped financial development.

For developing countries the French legal origin countries are mainly in Africa and it may be standing as a proxy for other (unmeasured) deficiencies in state capacity in many African countries. In any case how important the legacy of the formal legal system is rather moot where much too frequently in developing countries the enforcement of whatever the laws are in the statute books is quite weak, and the courts are hopelessly clogged and corrupt. Preoccupation with legal form and structure, overlooking law's actual operation and interaction with social life can be highly misleading. It should also be recognized that with weak markets for related transactions the net benefit from the transplanting of a European legal system replacing the indigenous customary system was in many cases rather limited. Kranton and Swamy (1999) show in a study of the impact of the introduction of civil courts in British India on the agricultural credit markets of the Bombay Deccan that while it led to increased competition, it reduced lenders' incentives to subsidize farmers' investments in times of crisis, leaving them more vulnerable in bad times, with insurance markets largely absent).

\section{IV}

In the previous sections we have discussed the role of institutions securing property rights and democratic rights and those facilitating economic coordination in explaining variations in economic performance. One of the as yet inadequately resolved issues in institutional economics in the context of underdevelopment is why dysfunctional institutions often persist for a long time. Why doesn't the social evolutionary process select 'fitter' institutions? In the recent literature on applications of evolutionary game theory to institutional change--see, for example, Bowles (2003) -- it is recognized that while efficiency generally contributes to a differential advantage in replication, given the positive and negative interactions of one institution with other institutions (involving their complementarity and crowding-out) and the payoffs to adherence to 
particular institutions being dependent on adherence by others, it is highly unlikely that efficiency and success in replication will always go together.

Before we proceed any further we should clarify a question about 'efficient' or 'inefficient' institutions that some economists are prone to ask. We want to be upfront about not necessarily referring to Pareto-efficiency. We'll more often regard a movement toward a productivity-enhancing institution to be a change in the right direction. The Pareto criterion and insistence on unanimity are much too stringent (and politically a non-starter) for most discussions of institutional change. In any case when one is in search of Pareto efficiency, to make the compensating transfers from gainers to losers incentive-compatible in a situation where the valuation of gainers and losers is private information, it may be extremely difficult to change institutions even with no frictions at all in bargaining (beyond this information problem). 22

The history of underdevelopment suggests that a major stumbling block to beneficial institutional change in many poor countries lies in the distributive conflicts and asymmetries in bargaining power among social groups. The 'old' institutional economists (including Marxists) used to point out how a given institutional arrangement serving the interests of some powerful group or class acts as a long-lasting barrier (or 'fetter', to quote a favorite word of Marx) to economic progress. As was suggested in Bardhan (1989) and Knight (1992), the 'new' institutional economists sometimes 23 understated the tenacity of vested interests, the enormity of the collective action problem in bringing about institutional change, and the differential capacity of different social groups in mobilization and coordination. The collective action

22 See Mailath and Postlewaite (1990) for a demonstration of this in the case of collective action on a public project.

23 North (1990) is an exception in this tradition. He points to the contrasting and path-dependent processes of change in bargaining power of the ruler versus the ruled in different countries, particularly in the context of the fiscal crisis of the state. In an earlier historical literature on the transition from feudalism in Europe, Brenner (1976) had provided a major departure from the usual analysis of transition in terms of demography or market conditions: he provided a detailed analysis of the contrasting experiences of transition in different parts of Europe (those between western and eastern Europe and those between the English and the French cases even within western Europe) in terms of changes in bargaining power of different social groups or in the outcomes of social conflicts. Brenner shows that much depends, for example, on the cohesiveness of the 
problem can be serious even when the change would be Pareto-superior for all groups. There are two kinds of collective action problems involved: one is the well-known free-rider problem about sharing the costs of bringing about change, the other is a bargaining problem where disputes about sharing the potential benefits from the change may lead to a breakdown of the necessary coordination. There are cases where an institution, which nobody individually likes, persists as a result of a mutually sustaining network of social sanctions when each individual conforms out of fear of loss of reputation from disobedience. 24 Potential members of a breakaway coalition in such situations may have grounds to fear that it is doomed to failure, and failure to challenge the system can become a self-fulfilling prophecy.

The problem may be more acute when, which is more often the case, there are winners and losers from a productivity-enhancing institutional change. The costs of collective action of such a change may be too high. This is particularly the case, as we know from Olson (1965), when the losses of the potential losers are concentrated and transparent, while gains of the potential gainers are diffuse 25 (or uncertain for a given individual, even though not for the group, as suggested by Fernandez and Rodrik (1992)). There is also the inherent difficulty, emphasized by Dixit and Londregan (1995), that the potential gainers cannot credibly commit to compensate the losers ex post. 26 Ideally, the state could issue long-term bonds to buy off the losers and tax the gainers to repay. But in many developing countries there are serious limitations to the government's ability to tax, and its credibility in keeping inflation under control, and the bond market is thin. There is also the fear losers have that once they give up an existing institution, they may lose the locus standi in lobbying with a future government when the promises are not

landlords and peasants as contending groups and their ability to resist encroachments on each other's rights and to form coalitions with other groups in society

24 For a well-known static analysis of such a case, see Akerlof (1984). For a more complex model in terms of stochastic dynamic games explaining evolution of local customs or conventions, see Young (1998).

25 As Machiavelli reminds us in The Prince (1513), Ch. VI, 'the reformer has enemies in all those who profit by the old order, and only lukewarm defenders in all those who would profit by the new'.

26 Of course, some societies may be able to develop in repeated situations appropriate norms of compensation to losers, but preservation of such a norm itself may require collective action. 
kept ('exit' from a current institutional arrangement damaging their 'voice' in the new regime in future), and so they resist a change today.

One can also formalize the obstruction by vested interests in terms of a simple Nash bargaining model, where the institutional innovation may shift the bargaining frontier outward (thus creating the potential for all parties to gain), but in the process the disagreement payoff of the weaker party may also go up (often due to better options of both 'exit' and 'voice' that institutional changes may bring in their wake), and it is possible for the erstwhile stronger party to end up losing in the new bargaining equilibrium (how likely this is will, of course, depend on the nature of shift in the bargaining frontier and the extent of change in the disagreement payoffs). 27 As Robinson (1998) has emphasized in his theory of predatory states, it may not be rational, for example, for a dictator to carry out institutional changes that safeguard property rights, law enforcement, and other economically beneficial structures even though they may fatten the cow which the dictator has the power to milk, if in the process his pre-existing rentextraction machinery has a chance of being damaged or weakened. He may not risk upsetting the current arrangement for the uncertain prospect of a share in a larger pie. Acemoglu and Robinson (2002) develop a theory where incumbent elites may want to block the introduction of new and efficient technologies because this will reduce their future political power; they give the example from 19th-century history when in Russia and Austria-Hungary the monarchy and aristocracy controlled the political system but feared replacement, and so they blocked the establishment of institutions that would have facilitated industrialization. These replacement threats are, of course, often driven by extreme inequality in society.

In explaining the divergent development paths in North and South America since the early colonial times, Engerman and Sokoloff (2002) have provided a great deal of evidence of how in societies with high inequality at the outset of colonization institutions evolved in ways that restricted to a narrow elite access to political power and opportunities for economic advancement. Initial unequal conditions had long lingering effects, and through their influence on 
public policies (in distribution of public land and other natural resources, public investment in primary education and other infrastructure, the right to vote and in secret, patent law, corporate and banking law, etc.) tended to perpetuate those institutions and policies that atrophied development. Even in countries where initially some oligarchic entrepreneurs are successful in creating conditions (including securing their own property rights) for their own economic performance, as long as that oligarchy remains powerful, they usually get away with raising entry barriers for new or future entrepreneurs, and this blocks challenges to their incumbency and thus sometimes new technological breakthroughs. See Acemoglu (2003) for a theoretical analysis of this kind of dynamic distortion in oligarchic societies even when property rights are protected for the initial producers.

The classic example of inefficient institutions persisting as the lopsided outcome of distributive struggles relates to the historical evolution of land rights in developing countries. In most of these countries the empirical evidence suggests that economies of scale in farm production are insignificant (except in some plantation crops) and the small family farm is often the most efficient unit of production. Yet the violent and tortuous history of land reform in many countries suggests that there are numerous road blocks on the way to a more efficient reallocation of land rights put up by vested interests for generations. Why don't the large landlords voluntarily lease out or sell their land to small family farmers and grab much of the surplus arising from this efficient reallocation? There clearly has been some leasing out of land, but problems of monitoring, insecurity of tenure and the landlord's fear that the tenant will acquire occupancy rights on the land have limited efficiency gains and the extent of tenancy. The land sales market has been particularly thin (and in many poor countries the sales go the opposite way, from distressed small farmers to landlords and money-lenders). With low household savings and severely imperfect credit markets, the potentially more efficient small farmer is often incapable of affording the going market price of land. Binswanger, Deininger and Feder (1995) explain it in terms of land as a preferred collateral (and also carrying all kinds of tax advantages and speculation opportunities for the wealthy) often having a price above the capitalized value of

27 This is the case even if we abstract from the usual case of deadlocks arising in bargaining with 
the agricultural income stream for even the more productive small farmer, rendering mortgaged sales uncommon (since mortgaged land cannot be used as collateral to raise working capital for the buyer). Under these circumstances and if the public finances (and the state of the bond market) are such that landlords cannot be fully or credibly 28 compensated, land redistribution will not be voluntary.

Landlords resist land reforms also because the leveling effects reduce their social and political power and their ability to control and dominate even non-land transactions. ${ }^{29}$ Large land holdings may give their owner special social status or political power in a lumpy way (so that the status or political effect from owning 100 hectares is larger than the combined status or political effect accruing to 50 new buyers owning 2 hectares each). Thus the social or political rent of land ownership for the large landowner will not be compensated by the offer price of the numerous small buyers. Under the circumstances the former will not sell, and inefficient (in a productivity sense, not in terms of the Pareto criterion) land concentration persists.

Of course, even in the context of increasing returns to land ownership in terms of political rent, land concentration is not always the unique or stable political equilibrium. Much depends on the nature of political competition and the context-specific and path-dependent formations of political coalitions. An interesting example of this in terms of comparative institutional-historical analysis is provided by Nugent and Robinson (1998). Holding constant both colonial background and crop technology, they compare the divergent institutional (particularly in terms of small holder property rights) and growth trajectories of two pairs of former Spanish colonies in the same region (Costa Rica and Colombia, on the one hand, and El Salvador and Guatemala, on the

incomplete information, with possible misrepresentation of the 'type' of the bargaining players.

28 This is particularly the case if, as we have mentioned before, the government has limited ability to tax and low credibility in promising not to inflate away the value of bonds with which landlords are compensated.

29 Busch and Muthoo (2002) develop a model where land redistribution may adversely affect a landlord's bargaining power in other markets (labor or credit). The inability to make binding commitments prevents the poor from committing not to exploit their increased bargaining power following land redistribution; and, of course, being wealth-constrained they cannot compensate the landlords upfront either. The greater is the degree of inequality in the players' bargaining powers the more likely it is that inefficient institutions will persist. 
other) producing the same principal crop (coffee). The political fragmentation of elites often helps in overcoming obstacles to institutional development. In Costa Rica, for example, the elites of different towns were induced to compete with each other for popular support which they did by offering private property rights to smallholders. In El Salvador and Guatemala, on the other hand, the national elite remained unified in opposition to such an institutional change. Institutional economics will be richer with more such comparative historical studies (instead of more cross-country regressions).

An important aspect of political rent, that is overlooked in the usual calculations of the surplus generated by a given institutional change, is that all sides are really interested in relative, rather than absolute, gain or loss. In a power game, as in a winner-take-all contest or tournament, it is not enough for an institutional change to increase the surplus for all parties concerned to be acceptable. One side may gain absolutely, and yet may lose relative to the other side, and thus may resist change. If, in a repeated framework, both sides have to continue to spend resources in seeking (or preserving) power or improving their bargaining position in future, and if the marginal return from spending such resources for one party is an increasing function of such spending by the other party (i.e. power seeking efforts by the two parties are 'strategic complements'), it is easy to see why the relative gain from an institutional change may be the determining factor in its acceptability. 30

That collective action problems in orchestrating institutional change from a low-level to a higher-level equilibrium are rendered particularly difficult by distributive conflicts are now slowly being recognized in both the macro and microeconomic literature. In macroeconomic comparisons of East Asia and Latin America in the last quarter of the twentieth century the point has been made that when wealth distribution is relatively egalitarian, as in large parts of East Asia (particularly through land reforms and widespread expansion of education and basic health services), it has been somewhat easier to enlist the support of most social groups (and isolate the 
extreme political wings of the labor movement) in making short-run sacrifices at times of macroeconomic crises and coordinating on stabilization and growth-promoting institutions and policies. 31 Rodrik (1998) cites cross-country evidence for his hypothesis that the economic costs of external shocks are magnified by distributional conflicts that are triggered, and this diminishes the productivity with which a society's resources are utilized. Recently Djankov et al (2003) referred to the differences between countries in what they call 'civic capital', determining the differential location of their Institutional Possibility Frontier (which traces the trade-off between social losses due to disorder and the associated private expropriation and losses due to state expropriation) in different countries. Our point is to emphasize the decisive influence of distributive conflicts in determining the availability of 'civic capital' in a country.

Below the aggregative or macro level there are many local self-governing institutions (either elected local government bodies in charge of delivering local public goods like roads, extension service, and public health and sanitation, or rural community organizations in charge of management of environmental resources like forests, fishery, irrigation, and grazing lands or urban neighborhood associations in charge of crimewatch or cultural-cum-social solidarity promoting activities), where distributive conflicts may sometimes lead to institutional failures. In areas of high social and economic inequality the problem of 'capture' of even elected local government bodies by the local elite can be severe, and the poor and the weaker sections of the population may be left grievously exposed to their mercies and their malfeasance ${ }^{32}$. Thus one beneficial byproduct of land reform, underemphasized in the usual economic analysis, is that such reform, by changing the local political structure in the village, gives more 'voice' to the poor and induces them to get involved in local self-governing institutions. In other cases, the problem of elite capture may be less, but that of elite 'exit' is quite serious in causing the erosion of political support from the provision of local public goods. When, for example, the rich do not send their

28. For a model of power-seeking on these lines to explain why two parties may not agree to obviously mutually advantageous transactions, even when there are simple enforceable contracts and side transfers of fungible resources to implement them, see Rajan and Zingales (1999).

31 See, for example, Campos and Root (1996).

32 For a theoretical analysis of the elite capture problem in the context of decentralization, see Bardhan and Mookherjee (forthcoming). 
children to local public schools and do not use the local health services, the public provision structure often crumbles as is familiar in both rich and poor countries.

Similar problems, arising from inequality, may afflict local non-government, often informal, community organizations in developing countries. The relationship between inequality and collective action (both in the sense of participation in a regulatory group organization and that of contributing to provision or conservation of some common resource) is an underresearched area in economics. For a brief account of the theoretical and empirical literature on this question, see Baland and Platteau (forthcoming). Here let us generally note that while the effect of inequality is in general ambiguous, there are many cases where the net benefits of coordination for each individual may be structured in such a way that in situations of marked inequality some individuals may not participate or contribute to the cost of collective action, and the resulting outcome may be more inefficient than in the case with greater equality ${ }^{33}$. Inequality may also lead to bargaining disputes arising from the distribution of benefits of collective action, as we have mentioned above. Besides, the negotiation and enforcement costs for some cooperative arrangements may go up with inequality. In such situations collective institutional structures and opportunities for cooperative problem-solving may be foregone by societies that are sharply divided along social and economic lines.

In this paper we have first tried to extend the existing quantitative literature on the effect of the institutions that protect property rights on economic development across countries by introducing a state antiquity variable that can be an identifying instrument, alternative to the now

33 See Bardhan and Singh (2004) for a model where cooperation is beneficial in providing a public infrastructural facility, but subject to defection, and is supported by trigger strategy punishments in a repeated game. The paper explores the relationship between the nature of cooperation (size and composition of coalitions) and underlying inequality in the distribution of private productive assets. 
widely-used colonial settler mortality variable, since the latter has been found to be unsatisfactory in some respects. State antiquity in the sense of a continuing history of state structure and bureaucratic culture seems to be a good predictor of the security of property rights in developing countries that were colonies of Europe as well as others that were not (not surprisingly, the state antiquity index is in general much lower for sub-Saharan Africa and Latin America than for Asia). Then we show that for some non-income social aspects of development (like literacy) an institutional variable like an index of participatory rights and democratic accountability is a better explanatory variable than the property rights institutions. We then expand our enquiry in exploring the effects of a society's other institutions that historically have had a large impact on the pace and pattern of development. In a qualitative comparative-historical analysis we discuss how in some countries the state at the initial stages of industrialization may play a crucial catalytic role in coordinating development (and providing appropriate positive and negative incentives) particularly in raising long-term finance for industrial development; this has been necessary even in countries which have had some age-old ethnic networks for long-distance trade and credit. In some other countries the state has not been successful in this role, given their low institutional capacity and their inability to rise above the inevitable political and rent-seeking pressures.

The state's failure in addressing coordination problems in financial markets in some of these countries has been part of a more general failure in resolving various collective action problems in providing public goods and social infrastructure. The institutional failure in collective action problems is often a strategic outcome of fundamental distributive conflicts in society. In the last part of the paper we enumerate the various processes through which initial inequality may result in the persistence of dysfunctional institutions in many poor countries. The hypothesis that high inequality predicts a high probability of 'bad' institutions, and the latter in turn predict low income could in principle be tested from the kind of cross-country data that we use in the early parts of the paper. But testing this hypothesis is problematic. Inequality, after all, is highly endogenous, and any such exercise will be afflicted by the same kinds of problems as the ones Banerjee and Duflo (2003) have pointed out about the cross-country regressions on inequality and growth. One possibility is to use density of population in some historically early 
period as an instrument for predicting high inequality. As we have mentioned in connection with our regressions in Table $\mathrm{V}$, weak political rights today are associated with high density of population in 1500 , possibly indicating that in areas of labor abundance relative to land and other resources workers and peasants have weak political power and equality of political power may have been difficult to establish. But political inequality and economic inequality are not closely associated. It is likely to be the case that, other things remaining the same, in areas where labor is scarce, labor may be valued more highly and thus there may be less inequality, as has been argued by Engerman and Sokoloff (2002) in their comparison of North America with the tropical parts of Latin America. Land abundance and labor scarcity have not, however, helped Africans in the same away as North Americans for various historical reasons. Also, by this logic compared to Latin America and Africa, Asia (where density of population has been higher) should have more economic inequality, not less, as is actually the case. This may have something to do with inheritance practices. China and India, unlike Western Europe, North America and Latin America, historically did not have primogeniture, but equal partition (among sons) and subdivision of land, so there is a built-in tendency in Asia towards equality. There are also other factors involved. A historical density of population variable is therefore likely to be a 'weak instrument'. For these reasons and in the absence of inter-country data on many of the relevant factors we have confined our discussion of the institutional impact of distributive conflicts to the qualitative level.

This paper thus mixes methods of analysis: section II uses cross-country regressions, whereas sections III and IV use a comparative-historical analysis. We have at the end of section II discussed some of the limitations of the cross-country statistical analysis. In contrast comparative-historical analysis when done properly may give us some general insights into the mechanisms and processes involved, but does not clinch issues in terms of quantification or allow us to control for other factors that may be simultaneously impinging on the variable in question or sort out the endogeneity or reverse causality issues. For quite a long time to come both methods will have to be utilized, with full consciousness of the limitations of either, and the conflicting issues will not be resolved until much more detailed datasets particularly involving panels within at least some major countries become available. 


\section{References}

D.Acemoglu, S. Johnson, and J. A. Robinson, "The Colonial Origins of Comparative Development: An Empirical Investigation”, American Economic Review, 91 (5), 2001, 1369-1401 D.Acemoglu, S. Johnson, and J. A. Robinson, “A Response to Albouy”, unpublished, MIT, 2005.

D. Acemoglu and J.A.Robinson, "Economic Backwardness in Political Perspective", NBER Working Paper no. 8831, 2002.

D. Acemoglu, "Why Not a Political Coase Theorem? Social Conflict, Commitment and Politics", MIT, November 2002.

D. Acemoglu, "The Form of Property Rights: Oligarchic vs. Democratic Societies”, MIT, September 2003.

G. A. Akerlof, An Economic Theorist's Book of Tales, Cambridge University Press, Cambridge, 1984.

D. Albouy, "The Colonial Origins of Comparative Development: A Reinvestigation of the Data", unpublished, University of California, Berkeley, 2004.

M. Aoki, Towards a Comparative Institutional Analysis, MIT Press, 2001.

M. Aoki, K. Murdock, and M. Okuno-Fujiwara, "Beyond the East Asian Miracle: Introducing the Market Enhancing View", in M. Aoki, H. Kim and M. Okuno-Fujiwara (eds.), The Role of 
Government in East Asian Economic Development: Comparative Institutional Analysis, Oxford University Press, 1997.

B. Armendariz de Aghion, "Development Banking”, Journal of Development Economics, 60 (1), 1999, 83-100.

J.-M. Baland and J.-P. Platteau, "Collective Action on the Commons: The Role of Inequality", in J.-M. Baland, P. Bardhan, and S. Bowles (eds.), Inequality, Collective Action and Environmental Sustainability, Princeton University Press, forthcoming.

A. Banerjee and E. Duflo, "Inequality and Growth: What Can the Data Say?", unpublished, MIT, 2003.

P. Bardhan, "The New Institutional Economics and Development Theory: A Brief Critical Assessment", World Development, 1989, 1389-95.

P. Bardhan, Scarcity, Conflicts, and Cooperation, MIT Press, Cambridge, MA, 2005.

P. Bardhan and D. Mookherjee, "Decentralization and Accountability in Infrastructure Delivery in Developing Countries", Economic Journal, forthcoming.

P. Bardhan and C. Udry, Development Microeconomics, Oxford University Press, Oxford, 1999.

P. Bardhan and N. Singh, "Inequality, Coalitions, and Collective Action”, unpublished, Berkeley, 2004.

C.A. Bayly, Rulers, Townsmen and Bazaar: North Indian Society in the Age of British Expansion 1770-1870, Cambridge University Press, Cambridge,1983.

H.P. Binswanger, K. Deininger, and Gershon Feder, "Power, Distortions, Revolt and Reform in Agricultural Land Relations" in J.R. Behrman and T.N. Srinivasan (eds.), Handbook of Development Economics III, Elsevier, Amsterdam, 1995.

V. Bockstette, A. Chanda, and L. Putterman, "States and Markets: The Advantage of an Early Start," Journal of Economic Growth, 7, 2002: 347-369.

S. Bowles, Microeconomics: Behavior, Institutions and Evolution, Princeton University Press, Princeton, 2004. 
R. Brenner, "Agrarian Class Structure and Economic Development in Pre-industrial Europe", Past and Present, 70(1), 1976, 30-70.

L.A.Busch and A. Muthoo, "Power and Inefficient Institutions", Essex University, 2002.

M. Da Rin and T. Hellman, "Banks as Catalysts for Industrialization", unpublished paper, Stanford University, 1996.

M. Dewatripont, and E. Maskin, "Credit and Efficiency in Centralized and Decentralized Economies”, _Review of Economic Studies, 62(4),1995, 541-55.

A. K. Dixit and J. Londregan, "Redistributive Politics and Economic Efficiency", American Political Science Review, 89(4),1995, 856-66.

S. Djankov, E. L. Glaeser, R. La Porta, F. Lopez-de-Silanes, and A. Shleifer, "The New Comparative Economics", NBER Working Paper no. 9608, 2003.

B. Eichengreen, 'Capitalizing on Globalization', Asian Development Review, vol. 19(1), 2002.

S. L. Engerman and K. L. Sokoloff, "Factor Endowments, Inequality, and Paths of Development among New World Economies", NBER Working Paper, October 2002.

P. Englebert, State Legitimacy and Development in Africa, Lynne Rienner Publishers, Boulder, 2000 .

R. Fernandez and D. Rodrik, "Resistance to Reform: Status Quo Bias in the Presence of Individual-Specific Uncertainty”, American Economic Review, 81(5), 1991, 1146-55.

A. Gerschenkron, Economic Backwardness in Historical Perspective, Harvard University Press, Cambridge, 1962.

A. Greif, "Institutions and International Trade: Lessons from the Commercial Revolution", American Economic Review, 82(2), 1992, 128-33.

A. Greif, "Microtheory and Recent Developments in the Study of Economic Institutions through Economic History", in D. M. Kreps and K.F. Wallis (eds.), Advances in Economic Theory, Cambridge University Press, vol. II, 1997. 
A. Greif, P. Milgrom and B. Weingast, "Coordination, Commitment, and Enforcement: The Case of the Merchant Guild”, Journal of Political Economy, 102(3),1994, 745-76.

J. I. Herbst, States and Power in Africa: Comparative Lessons in Authority and Control, Princeton University Press, Princeton, 2000.

B. Holmstrom and J. Roberts, "The Boundaries of the Firm Revisited", Journal of Economic Perspectives, 12, 1998, 73-94.

D. Kaufman, A. Kraay, and P. Zoido-Lobatón, "Governance Matters II -- Updated Indicators for 2000/01”, World Bank Policy Research Department Working Paper no. 2772, Washington DC, 2002.

T. Khanna and Y.Yafeh, "Business Groups and Risk Sharing around the World", Harvard Business School Working Paper no. 01-041, 2000.

J. Knight, Institutions and Social Conflict, Cambridge University Press, New York, 1992.

R. E. Kranton and A.V. Swamy, "The Hazards of Piecemeal Reform: British Civil Courts and the Credit Market in Colonial India”, Journal of Development Economics, 58(1), 1999, 1-24.

N.R. Lamoreaux, Insider Lending: Banks, Personal Connections, and Economic Development in Industrial New England, Cambridge University Press, Cambridge, 1994.

N.R. Lamoreaux and J.L. Rosenthal, “Legal Regimes and Business’s Organizational Choice : A Comparison of France and the United States during the Mid-Nineteenth Century”, American Law and Economics Review, forthcoming.

R. La Porta, F. López-de-Silane, A. Shleifer, and R. Vishny, "The Quality of Government", Journal of Law, Economics and Organization, 15, 1998, 222-79.

R. La Porta, F. López-de-Silanes and G. Zamarripa, "Related Lending”, Quarterly Journal of Economics, 118 (1), 2003.

J. S. Li, "Relation-based versus Rule-based Governance: An Explanation of the East Asian Miracle and Asian Crisis", Review of International Economics, 11(4), 2003, 651-73. 
Y. Lin, "Industrial Structure, Technical Change, and the Role of Government in Development of the Electronics and Information Industry in Taipei, China”, Economics and Research Department Working Paper, Asian Development Bank, Manila, May 2003.

D. Ma, "Growth, Institutions and Knowledge: A Review and Reflection on $18^{\text {th }}-20^{\text {th }}$ Century Chinese Historiography", Australian Economic History Review, 44(3), 2004, 259-77.

G. J. Mailath and A. Postlewaite, "Asymmetric Information Bargaining Problems with Many Agents", Review of Economic Studies, 57(3), 1990, 351-68.

N. Maurer and S. Haber, "Related Lending and Economic Performance: Evidence from Mexico", unpublished, Stanford, 2004.

C. McEvedy and R. Jones, Atlas of World Population, Penguin Books Ltd., UK, 1978.

J. McMillan and C. Woodruff, "Interfirm Relationships and Informal Credit in Vietnam", Quarterly Journal of Economics, 114(4), 1999, 1285-1320.

L. Menkhoff and C. Suwanaporn, "The Rationale of Bank Lending in Pre-Crisis Thailand", ZEF Discussion Paper no. 66, Bonn, 2003.

P. Milgrom, D. C. North, and B. Weingast, "The Role of Institutions in the Revival of Trade: The Medieval Law Merchant, Private Judges, and the Champagne Fairs", Economics and Politics, 2(1), 1990, 1-23.

K. Murphy, A. Shleifer, and R. Vishny, "Industrialization and the Big Push", Journal of Political Economy, 97(5),1989, 1003-26.

D.C. North, Structure and Change in Economic History, Norton, New York, 1981.

D.C. North, Institutions, Institutional Change and Economic Performance, Cambridge University Press, New York, 1990.

J.B.Nugent and J. Robinson, "Are Endowments Fate? On the Political Economy of Comparative Institutional Development”, Dept. of Economics, USC, December 1998.

M.Olson, The Logic of Collective Action: Public Goods and the Theory of Groups, Harvard University Press, Cambridge, MA., 1965. 
O. Olsson, "Unbundling Ex-Colonies: A Comment on Acemoglu, Johnson, and Robinson", unpublished, Göteborg University, 2005.

W. G. Ouchi, "Markets, Bureaucracies, and Clans", Administrative Science Quarterly, 25(1), $1980,129-41$.

H. Pack, Review of Parente and Prescott (2000), Journal of Development Economics, 70(1), 2003, 243-47.

S. L. Parente and E. C. Prescott, Barriers to Riches, MIT Press, Cambridge, MA, 2000.

P. M. Parker, National Cultures of the World: A Statistical Reference, Cross-Cultural Statistical Encyclopedia of the World Vol. 4, Greenwood Press, Westport, 1997.

A. Przeworski and F. Limongi, "Political Regimes and Economic Growth", Journal of Economic Perspectives, 7(3), 51-70, 1993.

R. R. Rajan and L. Zingales, "The Tyranny of the Inefficient: An Enquiry into the Adverse Consequences of Power Struggles", University of Chicago, Graduate School of Business, Working Paper, January 1999.

S.G.Redding, The Spirit of Chinese Capitalism, Walter de Gruyter, New York, 1990.

J. A. Robinson, “Theories of 'Bad' Policy”, Journal of Policy Reform, 3, 1998, 1-46.

H. Rosenthal and E. Berglof, "The Political Origin of Finance: The Case of Federal Bankruptcy Law in the United States", Weatherhead Center Conference paper, Harvard University, 2003.

D. Rodrik, "Where Did All the Growth Go? External Shocks, Social Conflicts, and Growth Collapses”, NBER Working Paper no. 6350, Cambridge, MA, 1998.

P. Rosenstein-Rodan, "Problems of Industrialization of Eastern and Southeastern Europe", Economic Journal, 53, 1943, 202-11.

D. Rodrik, A. Subramanian and F. Trebbi, "Institutions Rule: The Primacy of Institutions over Geography and Integration in Economic Development”, Journal of Economic Growth, 9(2), 2004, 131-65. 
D. W. Rudner, Caste and Capitalism in Colonial India: The Nattukottai Chettiars, University of California Press, Berkeley, 1994.

O.Williamson, The Economic Institutions of Capitalism, Free Press, New York, 1985.

H. P. Young, Individual Strategy and Social Structure: An Evolutionary Theory of Institutions, Princeton University Press, Princeton, 1998. 